\title{
RECONSTRUCTION OF THE JUVENILE CRIMINAL JUSTICE SYSTEM AND THE GIVING OF DIVERSION
}

\author{
Muhaimin \\ Research and Development Board for Law and Human Rights \\ Corresponding email: eminaltair@gmail.com
}

Paper received on: 25-02-2021; Revised on: 14-04-2021; Approved to be published on: 04-04-2021;

DOI: http://dx.doi.org/10.30641/dejure.2021.V21.253-266

\begin{abstract}
Children are not to be punished but to be given guidance and development, so that they grow and develop as completely normal, healthy and intelligent children. Sometimes children experience situations that make them commit illegal acts. Even so, children who break the law are not worthy of punishment, let alone put in prison. Law Number 11 Year 2012 concerning Juvenile Criminal Justice System demands a reorientation of the purpose of punishment which has an impact on the operation of the Juvenile Criminal Justice System. The formulation of the objectives of restorative justice and diversion mechanisms which are recognized as mechanisms for handling crimes committed by children demands that the performance of the criminal justice sub-system change its orientation. The problem of this research was how the construction and reconstruction of the giving of diversion are. This research used descriptive analysis method and normative juridical approach. Children are part of citizens who must be protected as a generation to continue the leadership of the Indonesian nation. The current ideal construction for children who are in conflict with the law applies the Law of Juvenile Justice System where children aged 7 years can be given diversion in the trial process. Article 21 of the Law of Juvenile Criminal Justice System and Government Regulation No. 65 Year 2015 concerning Guidelines for the Implementation of Diversion, children under 12 years of age who commit/are suspected of committing a criminal act shall then be returned to their parents and include them in education, coaching, and mentoring programs in government institutions or Social Welfare Organizing Institutions in institutions in charge of social welfare.
\end{abstract}

Keywords: justice system; juvenile criminal; diversion; restorative justice

\section{INTRODUCTION}

Children who commit criminal acts must continue to obtain legal protection in the court process for the best interest of the child, both legal protection for the child perpetrator of a criminal act, the implementation of examination of the child perpetrator of a criminal act, and the punishment of the child perpetrator of a criminal act.

Judging from the current existing conditions, the success of law enforcement is also closely related to the legal structure, namely the permanent form framework of the legal system that keeps the process within its boundaries. The structure consists of: the number and size of courts, jurisdiction (types of cases examined and the procedural law used), and the arrangement of the legislative body ${ }^{1}$.

\footnotetext{
Mosgan Situmorang, “Aspek Hukum Pemberantasan Tindak Pidana Korupsi Oleh Korporasi Dalam Bidang Perpajakan," Penelitian Hukum De Jure 20, no. 3 (2020): 337, https://ejournal.balitbangham.go.id/index.php/ dejure/article/view/128o/pdf.
}

One of the functions of criminal law is to limit and announce prohibited acts. These are referred to as rules of conduct, which have previously been established and aimed at citizens as acts that must be avoided under the threat of criminal sanctions. In addition, the law maintains a permanent state (status quo) as well as flexibly guards change. Law, especially criminal law, is designed to maintain order, as well as protect public and private interests. The society determines several very important interests that need to be maintained by a formal system of control. Therefore, the law must legally give the state power to enforce it. Law is an official system of social control, which may be applied if other forms of social control are ineffective ${ }^{2}$.

Law Number 11 Year 2012 regarding the Juvenile Criminal Justice System (SPPA) attempted to build a system that is able to

\footnotetext{
Muhaimin, "Penetapan Tersangka Tidak Ada Batas Waktu," Jurnal Penelitian Hukum De Jure 20, no. 2 (2020): 278, https://ejournal.balitbangham.go.id/ index.php/dejure/article/view/1165/pdf_1.
} 
provide a stronger legal basis for existing legal mechanisms by accommodating it with a mechanism in statutory provisions. This is a way out for mechanisms that have worked in society by involving law enforcement as part of the operation of this system.

In the Juvenile Criminal Justice System Law, the restorative program is operationalized in two ways, namely:

\section{a. Diversion Mechanism}

b. Through the mechanisms that work in the juvenile criminal justice system

In this case, Diversion must be understood as a Diversion Program, namely:

A program that refers certain criminal defendants before trial to community programs on job training, education, and the like, which if successfully completed may lead to the dismissal of the $\operatorname{charges}^{3}$ (a program aimed at a suspect before the trial process in the form of a community program such as job training, education and the like where if this program is deemed successful it will allow him to discontinue further criminal justice proceedings).

In the context of Juvenile Criminal Justice System, diversion is translated as a mechanism for the diversion of a criminal case which all parts of the criminal justice system are obliged to strive for, including the police as investigators, prosecutors and judges in exercising their judicial authority. In this context, diversion becomes an instrument in using restorative approach in handling criminal cases in which Duff states (as quoted by Lode Walgrave), "restorative justice is not alternative to punishment, but alternative punishment ${ }^{4}$."

Meanwhile, Stephen VP. Grvey states that restorative justice is a way of responding to crime. These two views provide legitimacy that restorative justice is not just an out of court settlement in handling criminal cases. In fact, placing the responsibility of implementing diversion on the officers is considered a tough choice because what is specified in the written rules compared to the actual situation in reality can be very different. There is a difference between the ideal concept which is formally

\footnotetext{
Bryan A. Garner (ed), Black's Law Dictionary (St. Paul, 2000).

4 Lode Walgrave, Restoration in Youth Justice (Chicago: University of Chicago, 2004).
}

determined in laws and regulations and a situation that is different in reality, causing officers to make policies according to their own considerations in response to the situation. Therefore, discretionary authority as a means of diversion in the criminal justice process can be exercised by judges, prosecutors, police and correctional officers as part of their sub-system ${ }^{5}$.

In the provisions of the Juvenile Criminal Justice System Law (UU SPPA), it is known that the terminology of children facing the law is children who are in conflict with the law, children who are victims of criminal acts, and children who are witnesses of criminal acts. Children in conflict with the law or in the Juvenile Criminal Justice System Law the terminology used is children who are 12 (twelve) years old, but not yet 18 (eighteen) years old, who are suspected of committing a criminal act. Children who are victims of criminal acts (Child Victims) are children under 18 (eighteen) years of age who have suffered physical, mental, and/or economic losses due to criminal acts. Children who are witnesses of criminal acts (Witness children) are children under the age of 18 (eighteen) who can provide information for the purposes of investigation, prosecution and examination in court about a criminal case that they have heard, seen, and/or experienced themselves (Article 1 number (2), number (3), number (4) and Article 5 of the Juvenile Criminal Justice System Law) ${ }^{6}$.

According to Lilik Mulyadi, the provisions of the Juvenile Criminal Justice System Law which determine the definition of a child as not yet 18 (eighteen) years old are incomplete. What if the child is not yet 18 (eighteen) years old but has been married and then divorced, is he/she included in the category of child or is he/she considered an adult? ${ }^{7}$

First, there is a view that says that if a child is not yet eighteen years old, and he/she has been married, he/she is assumed to be an adult. However, if the child is divorced and the age of the child is under eighteen years, then he/she is again categorized as a child. Aspect and assumption

\footnotetext{
5 Suhariyono AR Jufrina Rizal, Demi Keadilan Antologi Hukum Pidana dan Sistem Peradilan Pidana. (Jakarta: Pustaka Kemang, 2016).

6 Lilik Mulyadi, Wajah Sistem Peradilan Pidana Anak Indonesia (Bandung: Alumni, 2014).

7 Ibid. hal. 5
} 
of this dimension are based on the provisions of Article 1 number (1) of Law Number 23 Year 2002 concerning Child Protection, and Article 1 number (3) of the Juvenile Criminal Justice System Law. In essence, such view starts from a positivism perspective.

Second, there is another view that says that if so the child is still categorized as an adult. From a juridical perspective, it is impossible for a child who has been considered an adult, then retreated to be considered a child. These aspect and dimension are based on the dimension of civil law, the explanation of the provision of Article 20 of the Juvenile Criminal Justice System Law which reads, "Children who are married and not yet 18 (eighteen) years of age are still given civil rights and obligations as adult", and the interpretation of hermeneutics explains the provision of various laws, assuming the dimension of the context above, were categorized as adult, not child anymore. According to the polarization of the researcher's thought, the definition of child as regulated in the Juvenile Criminal Justice System Law, namely 12 (twelve) years old, but not yet 18 (eighteen) years old, who is suspected of having committed a criminal act, is not yet complete. Perhaps from a juridical, sociological and philosophical perspective, it would be relatively complete if the meaning was added by the phrase of "never married". The nature of this "never married" context is important for its existence, because if the child is not yet 18 (eighteen) years old, but has already been married, the child is not tried and is not the jurisdiction of juvenile justice anymore, but is equalized and enters the jurisdiction of justice for adults.

The enactment of Law Number 11 Year 2012 concerning the Juvenile Criminal Justice System (UU SPPA) demands a reorientation of the purpose of punishment which has an impact on the functioning of the Juvenile Criminal Justice System. The formulation of the objectives of restorative justice and diversion mechanism which is recognized as mechanism for handling crimes committed by children demands that the performance of the criminal justice sub-system change its orientation. If we refer to the objective of the criminal justice system, the use of the restorative approach as the goal of punishment causes the operation of this system to be out of track.
Comparing the achievement of the objectives of punishment using the restorative justice approach with the current criminal justice system shows a very different matter. On the one hand, the full state authority over punishment has created a criminal justice system that is only oriented towards solving criminal cases through one channel, namely through the criminal justice process. Meanwhile, restorative justice, with the paradigm it has developed, opens opportunities for alternative solutions to criminal cases through other channels outside the criminal justice system, including direct, free and independent mediation and reconciliation in determining the best and fairest criminal case settlement model ${ }^{8}$. With this approach, the settlement of criminal cases is no longer a state monopoly but also becomes part of the authority of each individual to find the best mechanism and solution to the problems they face.

From the above description and explanation, it is necessary to formulate the problem of this scientific paper, namely "How are the construction and reconstruction of diversion provision in the juvenile justice system?"

\section{RESEARCH METHOD}

The method used in this research is a normative juridical method. In a normative juridical research, the use of a statute approach is a definite thing. It is said to be definite, because in legal logic, normative legal research is based on research conducted on existing legal materials. Although, for example, the research was carried out because it saw a legal vacuum, this legal vacuum could be identified, because there were already legal norms that required further regulation in positive law ${ }^{9}$. In the context of this research, the approach was implemented towards legal norms contained in several laws and regulations such as Law Number 11 Year 2012 concerning the Juvenile Justice System, Law Number 23 Year 2002 concerning Child Protection and other laws and regulations.

\footnotetext{
8 Antonius Cahyadi, Runtuhnya Sekat Perdata dan Pidana: Studi Peradilan Kasus Kekerasan Terhadap Perempuan (Jakarta: Yayasan Obor Indonesia, 2008).

9 Peter Mahmud Marzuki, Penelitian Hukum (Jakarta: Kencana Prenada Media Group, 2006).
} 


\section{DISCUSSION AND ANALYSIS}

\section{Construction and Reconstruction of the Giving of Diversion}

In the view that diversion is a mechanism for the diversion of criminal cases through channels outside the criminal justice system, it is actually an interesting thing. This is clearly illustrated in the Supreme Court Regulation No. 4 Year 2014. Diversion is a process diversion in the long and very rigid system of solving juvenile cases. Meanwhile, Diversion Deliberation is a deliberation between parties involving children and parents/guardians, victims and/or their parents/ guardians, Community Advisors, Professional Social Workers, representatives and other involved parties to reach a diversion agreement through a restorative justice approach.

Therefore, the provisions in this law determine the objectives of Diversion in handling cases in which the perpetrator is a child: (Article 6)

1. Achieving peace between the victim and the child;

2. Resolving juvenile cases outside judicial process;

3. Preventing children from being deprived of their liberty;

4. Encourage the society to participate; and

5. Instilling a sense of responsibility to children

Considering that diversion is a (formal) criminal law institution and can also be seen as a form of restorative justice whose origin cannot be separated from the purpose of implementing diversion in the Juvenile Criminal Justice System, it is felt necessary to describe it as well. The reference to the description of restorative justice as the aim of implementing diversion in the Juvenile Criminal Justice System fully refers to the views expressed in a Working Paper compiled by Dr. Ridwan Mansyur, SH. MH.

According to Mansyur, the Indonesian Criminal Law System is entering a new phase in its development. One form of reform that exists in the Indonesian Criminal Law is the regulation of law in the perspective and achievements after criminal justice events and processes known as restorative justice. Restorative justice is different from retributive justice (emphasizing justice over retaliation) and restitutive justice (emphasizing justice over compensation).

In view of the development of criminal law science and the nature of modern punishment, it has introduced and developed what is called the Doer-Victims Relationship approach. A new approach that has replaced the action or doer approach or "daad-dader straftecht". Legal experts have introduced a formula for justice, especially in upholding human rights. Three aspects of the approach to assist a legal system for the purpose of law modernization and reform, namely in terms of structure, substance and culture, all of which are feasible to run in an integral, simultaneous and parallel manner.

Children are part of citizens who must be protected because they are the generation of the nation who in the future will continue the leadership of the Indonesian nation. Apart from being obliged to receive formal education such as school, every child must also receive moral education so that they can grow up to be useful figures for the nation and state. The demand is in accordance with the provisions of the Convention on the Rights of the Child which was ratified by the Government of Indonesia through Presidential Decree Number 36 Year 1990, which was also stated in Law Number 4 Year 1979 concerning Child Welfare and Law Number 23 Year 2002 concerning Child Protection and Law Number 11 Year 2012 concerning the Juvenile Criminal Justice System, all of which set out the general principles of child protection. Namely nondiscrimination, best interests of children, survival, growth and development and respect for children's participation.

According to Article 108 of the Juvenile Criminal Justice System Law, peace was prioritized over the formal legal process which came into effect two years after the Juvenile Criminal Justice System Law was enacted or August 1, 2014.

Mansyur further states that the Supreme Court responded to the Juvenile Criminal Justice System Law very progressively. Chairman of the Supreme Court of the Republic of Indonesia Muhammad Hatta Ali signed Supreme Court Regulation (PERMA) Number 4 Year 2014 concerning Guidelines for the Implementation of Diversion in the Juvenile Criminal Justice System even before the Government Regulation which is a 
derivative of the Juvenile Criminal Justice System Law was issued.

The important point of the aforesaid Supreme Court Regulation is that judges are obliged to resolve issues of children in conflict with the law with a diversion program, which is a very recent legal procedure in the criminal law system and reform in Indonesia. In addition, this Supreme Court Regulation contains procedures for implementing diversion which are the guidelines for judges in solving juvenile crimes, considering that there is no regulation that contains a diversionspecial procedural law for the Juvenile Criminal Justice System.

According to Mansyur, the diversion and restorative justice relationship can be explained by seeing the Juvenile Criminal Justice System as all elements of the criminal justice system involved in handling cases of children in conflict with the law, the Police, the Attorney General's Office and the Court as well as Community Advisors or Correctional Centers, Advocates or assistance providers, Special Guidance Institution for Children (LPKA), Temporary Child Placement Institutions (LPAS) and Social Welfare Organizing Institutions (LPKS) as institutions that handle children in conflict with law, starting from the point the child comes into contact with the justice system, determining whether the child will be released or processed in juvenile court, to the stage when the child will be given options, such as being released or inclusion in the institution of punishment in the corridor of restorative justice. It is in line with:

1. United Nations Declaration year 2000 on The Basic Principles on the Use of Restorative Justice Programs in Criminal Matters;

2. Vienna Declaration on Crime and Justice: "Meeting the challenges of the Twenty-First Century" points 27-28 on Restorative Justice; and

3. Eleventh United Nations Congress year 2005 in Bangkok on Crime Prevention and Criminal Justice in point 32: "Synergies and Responses: Strategic Alliances in Crime Prevention and Criminal Justice"

Mansyur further explains that according to the regulation in Supreme Court Regulation Number 4 Year 2014, there is no difference in understanding regarding diversion according to the Juvenile Criminal Justice System Law and the Supreme Court Regulation. Diversion is the diversion of settlement of juvenile cases from the criminal justice process to a process outside the criminal justice, which aims to: 1) achieve peace between the victim and the child; 2) resolve juvenile cases outside the justice process; 3) prevent children from being deprived of their liberty; 4) encourage the society to participate and 5) instill a sense of responsibility to children.

Mansyur says that the punishment for perpetrator of Juvenile Crime does not then achieve justice for the victim, considering that from the other side it still leaves its own problems that are not resolved even though the perpetrator has been convicted. Looking at the principles of child protection, especially the principle of prioritizing the best interests of the child, it is necessary to process the settlement of juvenile cases outside the criminal mechanism or commonly known as diversion. Punishment institutions are not a way to solve juvenile cases because they are prone to violations of children's rights. Therefore, a program and procedure are needed in the system that can accommodate case settlement, one of which is by using a restorative justice approach, through a legal reform that does not only change the law but also modifies the existing criminal justice system, so that all objectives what the law intended are achieved.

Mansyur's next view is that one form of restorative justice mechanism is dialogue which is known among the Indonesian society as "deliberation for consensus". So that diversion, especially through the concept of restorative justice, becomes a very important consideration in resolving criminal cases committed by children. If the diversion agreement is not fully implemented by the parties based on the report from the Correctional Center Community Guidance, the Judge will continue the case examination in accordance with the Juvenile Criminal Justice Procedural Law. Judges in making their decisions are obliged to consider the implementation of some of the diversion agreements.

Based on the provisions of Article 1 number 7 of the Juvenile Criminal Justice System Law, it is emphasized that Diversion is the diversion of the settlement of juvenile cases from the criminal justice process to a process outside of criminal justice. The purpose of implementing Diversion is 
to achieve peace between victims and perpetrators of child delinquency (perpetrators of juvenile crimes), resolve juvenile cases outside the justice process, prevent children from being deprived of liberty, encourage society to participate in solving juvenile cases, and instill a sense of responsibility towards children (see Article 6 letters a, b, c, d, and e of the Juvenile Criminal Justice System Law). Thus, diversion justice is the process of solving juvenile criminal cases involving the perpetrator, the victim, the perpetrator's family/ victim's family, and other related parties. Then, it is diverted to the process of resolving juvenile criminal cases outside the criminal justice process by involving the perpetrator, the victim, the perpetrator's family, the victim's family, other related parties, community counselors, society and professional social workers based on the Restorative Justice approach (see Article 8 paragraph (1) of the Juvenile Criminal Justice System Law), to jointly handle, resolve legal conflicts faced by children for the better, provide solutions, reconciliation, reassurance or resolve juvenile criminal cases to be the best settlement for children (the best interest for the children), not create retaliation which makes children become stigma.

In connection with the concept of diversion justice, Marlina commented on article 11 of the United Nations Standard Minimum Rules for the Administration of Juvenile Justice (The Beijing Rules), that diversion is a process of diverting children in conflict with the law, from the criminal justice system to the informal justice system, such as returning the children to community social institutions, both government (State) and nongovernment. This action is performed to avoid negative effects on the psyche and development of the children. Diversion is carried out by officers by exercising authority which is called discretion. Based on article 11.1 of The Beijing Rules ${ }^{10}$, it is emphasized that legal consideration for juvenile crime perpetrator must be given anywhere, outside the formal justice process or juvenile justice process that is not under formal court arrangements such as the District Court and the law used refers to the provisions of the 1985 Beijing Rules, or the national law in force in Indonesia. Thus, juvenile criminal cases should not be diverted to the court.

\footnotetext{
10 Article 11.1, “The Beijing Rules," Article 11.1 (Beijing, 1985).
}

It will be more effective if it uses a discretion in the form of a diversion justice with other sanctions.

According to the researcher, the juvenile justice which is in accordance with the two principles above is a diversion justice model by reconciling the principle of equality before the law with the Family Group Conferencing model from Wundersitz, the principle of ultimum remedium, the Children Protection Law (Law Number 35 Year 2014), The Juvenile Criminal Justice System Law (Law Number 11 Year 2012), taking into account The Beijing Rules General Assembly Resolution 40/33 of 29 November 1985, the Children Protection Act in South Australia which emphasizes the protection of victims and perpetrators of juvenile crime (The Children's Protection and Young Offender Act 1979) and the Juvenile Criminal Law in New South Wales (The Children's Criminal Protection Act 1987), of which article 56 a states: "Children have right and freedom before the law equal to those enjoyed by adults and in the process".

Based on the provisions of Article 56 a of The Children's Criminal Protection Act of New South Wales above, it can be said: "All children have the same rights and liberty before the law as legal process for adults".

The principle of equality before the law for children must be implemented in a diversion justice model. Marlina cites Wundersitz's opinion about diversion justice as follows: "unless the public interest requires, criminal proceedings should not be instituted against a child or young person if there is an alternative means of dealing with the matter". Based on Wundersitz's opinion, it can be explained that: If the public interest does not want the imposition of a crime punishment against a child, then the punishment must not be applied (given) to the child or youth. Punishment cannot be applied if there are other settlements that are beneficial for the child, for example by means of a diversion settlement ${ }^{11}$.

Furthermore, Marlina writes that in the Australian state of Tasmania, the Youth Justice Act 1997 allows the police to exercise direct discretion against juvenile crime perpetrator by providing informational warnings (Article 8 advice), written warnings (Article 10), warning

\footnotetext{
" Marlina, Peradilan Pidana Anak di Indonesia (Jakarta: Refika Aditama, 2012)
} 
through meetings, meetings with members of the society, conferencing through the diversion process (Articles 13-19) or being forwarded to the Court. The meeting held by the Police is the same as the wagga-wagga model and the result is declared as an official warning from the police. When a police officer gives an official warning there will be options given to the juvenile crime perpetrator, such as: paying compensation, making work accountability through community service activities for 35 hours for the needs of the victim through social institutions or other institutions or other actions deemed appropriate ${ }^{12}$.

Thus, implementing Diversion for children who are subject to imprisonment under 7 (seven) years is mandatory for the General (Special Court) who handles children who are in conflict with the law. The main objective of the implementation of the Diversion justice for children is to protect the interests and future of the children, both as perpetrator and as victim of criminal acts (see Article 59 of the Child Protection Law) ${ }^{13}$.

Marlina cited Bagir Manan's opinion in a speech on the opening and inauguration of a special courtroom for children at the District Court of Bandung on August 13, 2004, in principle, saying: the term crime should not be given to children who are in conflict with the law. Children should not be sentenced to maximum punishment because in essence children in conflict with the law are victims, victims of broken home from their families, victims of social conditions, victims of economic conditions, victims of educational and cultural conditions, and victims of acts of violence from the surrounding environment ${ }^{14}$.

A child commits delinquency or an act which if committed by an adult is a criminal act, in essence the child is also a victim of culture, a victim of economic neglect, a victim of education, a victim of power, a victim of injustice, a victim of social exploitation and a victim of policies in a country.

2 Ibid. hal. 165

13 UU No. 35 Tahun 2014, Pasal 59 "Pemerintah dan Lembaga negara lainnya berkewajiban dan bertanggungjawab untuk memberikan perlindungan khusus kepada anak dalam situasi darurat, anak yang berhadapan dengan hukum, anak dari kelompok minoritas dan teresolasi, anak tereksplotasi se (Jakarta, 2014).

14 Marlina, Peradilan Pidana Anak di Indonesia. Hal. 176
The criminal justice model for juvenile delinquents or children in conflict with the law can be resolved through two routes, namely: (a) the penal justice route, and (b) the non-penal justice route.

\section{a. The Penal Justice Route}

In addition to the restorative and diversion justice processes, juvenile criminal cases can also be resolved formally or in penal justice in court. The process of juvenile criminal justice in court can be based on the provisions of Article 7 number (2) letters $a$ and $b^{15}$ in conjunction with Article 9 number (2) letters $a, b, c$ and $d$ of the Juvenile Criminal Justice System Law ${ }^{16}$, which in essence state: (a) the criminal threat for a child who is brought to court for more than 7 (seven) years, the criminal act (delinquency) committed by the child is a repeat criminal act (delinquency), not the perpetrator of delinquency or a beginner criminal act; (b). diversion is not approved (rejected) by the victim and/or the victim's family, the criminal act is not a violation, is not a minor criminal act, a criminal act that causes the victim, the losses suffered by the victim exceeds the value of the local provincial minimum wage.

In connection with the juvenile criminal justice process in court, Marlina added: Criminal justice for children can also be carried out if the juvenile case is classified as a very serious delinquency case such as: "Murder, consuming alcohol, and road safety, apart from these serious cases, there are also juvenile cases which are decided with discretion" $"$.

Although the obligations of the Diversion justice are determined for children who have reached the age of 12 (twelve) years and have not exceeded the age of 18 (eighteen) years or

15 Undang-undang Republik Indonesia No. 11 Tahun 2012 Tentang Sistem Peradilan Pidana Anak, Diversi sebagaimana dimaksud pada ayat (1) dilaksanakan dalam hal tindak pidana yang dilakukan: a. diancam dengan pidana penjara di bawah 7 (tujuh) tahun; dan b. bukan merupakan pengulangan tindak pidana”. (Jakarta, 2012).

16 Undang-undang Republik Indonesia No. 11 Tahun 2012 Tentang Sistem Peradilan Pidana Anak, Pasal 9 ayat (2) UU SPPA, menegaskan: "Kesepakatan Diversi harus mendapatkan persetujuan korban dan/ atau keluarga Anak korban serta kesediaan Anak dan keluarganya, kecuali untuk: a. tindak pidana yang berupa pelanggaran; b. tindak pidana ringan; c. tindak, 2012.

${ }_{17}$ Marlina, Peradilan Pidana Anak di Indonesia. Hal. 182 
have reached the age of 12 (twelve) years and are married but have not exceeded the age of 18 (eighteen) years (see Article 2 of the Regulation of the Supreme Court of the Republic of Indonesia Number 4 Year 2014 concerning Guidelines for the Implementation of Diversion in the Juvenile Criminal Justice System dated July 24, 2014) can be tried formally (Penal Justice Route) in the General Court or in the Special Court for Children if the quality of the delinquency (criminal act) committed by the child attracts public attention, disturbs the public interest, is a serious delinquency (criminal act), such as: narcotics trafficking, criminal acts of terrorism, premeditated murder or other delinquency (criminal acts) that can disturb the society and the state.

Regarding the juvenile criminal justice process, Paul Hadisuprapto says that "Juvenile delinquency handling is part of the criminal policy which in its operation can use two routes, namely: (a). criminal policy in the penal route which is more repressive, and (b). criminal policy in the non-penal route which focuses more on preventive nature" 18 .

In connection with this criminal policy, Achmad Ubbe cited Barda Nawawi Arief's opinion, that in the "Explanatory Memorandum" and European Council Recommendation No. R (99) 19 regarding "Mediation in Penal Matters" penal mediation can be done with the models ${ }^{19}$ :

1) Informal Mediation

2) Traditional Village or Tribal Moots

3) Victim-Offenders Mediation

4) Reparation Negotiation Programs

5) Community Panels or Courts

6) Family and Community Group Conferences.

The juvenile criminal justice process through the court (Penal Justice Court) is a special process of juvenile justice, which means that the cases, delinquency or criminal acts committed by children are already a criminal act that attracts general attention, the modus operandi which is carried out is more professional in nature, is

18 Paulus Hadisuprapto, "Peradilan Restoratif Model Peradilan Anak Indonesia Masa Datang, Pidato Pengukuhan Guru Besar dalam Bidang Kriminologl pada Fakultas Hukum Universitas Diponegoro Semarang, tanggal 18 Februai 2006," 2006.

19 Ahmad Ubbe, Mediasi Penal dan Peradilan Adat (Jakarta, 2014). carried out by mens rea criminal, their actions have disturbed the interests and security of the public, for example: narcotics trafficking, engaging in criminal acts of terrorism, committing premeditated murder, committing a criminal act punishable by imprisonment of more than 7 (seven) years or committing a criminal act that fulfills the elements of Article 7 number (2) in conjunction with Article 9 number (2) of the Juvenile Criminal Justice System Law as described above.

\section{b. The Non-penal Justice Route}

The non-penal justice route is a model for juvenile criminal justice which is carried out in a non-litigation manner. The purpose of this justice is to protect the interests and future of children, prioritize the principle of the best interest for the juvenile delinquency, override the principle of ultimum remedium and are preventive in nature. Non-litigation justice against children in conflict with criminal law can be carried out if the juvenile delinquency is still classified as fair delinquency, ordinary delinquency, and prone delinquency (not criminal delinquency). The delinquency was committed in the absence of a criminal mens rea. Nomatively, the quality of the delinquency does not meet the elements of Article 7 number (2) in conjunction with Article 9 number (2) of the Juvenile Criminal Justice System Law, is punishable by imprisonment of less than 7 (seven) years, not a criminal act of repetition, and the loss does not exceed the provincial minimum wage.

With the formal implementation of the juvenile criminal justice process in court, efforts of legal protection for children, the society, the state, the juvenile criminal justice process in litigation and non-litigation can be realized. If the juvenile criminal justice in litigation and non-litigation is implemented properly, the request for a judicial review to the Constitutional Court on Article 96 in conjunction with Article 100 in conjunction with Article 101 of Law of the Republic of Indonesia Number 11 Year 2012 (State Gazette Year 2012, Number 153) concerning the Juvenile Criminal Justice System against the 1945 Constitution with Case Number: 110/PUU-X 2012, dated October 24, 2012, according to the researcher's opinion, there is no reason enough to submit a request for a judicial review and strangely for the request for judicial review a quo in the Decision Letter of the Constitutional Court Number: 110/PUU-X/2012, 
dated March 28, 2013, the Petitioners' petition was granted in full.

Judging from the lexical and grammatical meanings, the word reconstruction has the meaning of returning to its original state or restructuring (depicting) ${ }^{20}$. Bryan A. Garner states that, "reconstruction is the act or process of rebuilding, recreating, or reorganizing something", so that reconstruction here is interpreted as the process of rebuilding or re-creating or reorganizing something ${ }^{21}$. Andi Hamzah argues that reconstruction comes from the word reconstruction which is given the meaning of restructuring or rearranging and can also be given the meaning of reorganization ${ }^{22}$. Abu Husain Ahmad bin Faris bin Zakaria states that the meaning of reconstruction can be understood as update or re-actualization. These aspect and dimension have three meanings, namely: ${ }^{23}$

1. Reconstructing or updating with things that have been there before (reviving);

2. Reconstructing or updating something that has expired (patchwork);

3. Reconstructing or updating with completely new form/innovative creation.

The meaning and limitation of diversion contained in the Law, as a legal concept or what has become a legal institution in the Pancasila Legal System, clearly signals that diversion is a process of diverting the settlement of criminal cases. In diversion, there is a shift in the process of settlement of cases from what was in the court to outside the criminal justice.

To such understanding of diversion, there are problems that arise. Does the process of diverting something from one place to another mean completely removing the case settlement process from within a justice system out of the justice system? Does this mean that diversion

2o Lilik Mulyadi, Pengembalian Aset (Asset Recovery) Pelaku Tindak Pidana Korupsi (Jakarta: Kencana, 2020).

${ }^{21}$ Bryan A. Garner (ed), Black's Law Dictionary. Hal. 1278

22 Muhammad Khalid Ali, "Rekonstruksi Pengaturan Persidangan Tanpa Hadirnya Terdakwa Tindak Pidana Korupsi Dalam Sistem Peradilan Pidana Indonesia" (Brawijaya, 2019).

23 Ahmad Syafiq, "Rekonstruksi Pemidanaan Dalam Hukum Pidana Islam (Perspektif Filsafat Hukum)," Jurnal Pembaharuan Hukum 1, no. 2 (2014): 179. is a diversion from the process required by the criminal procedural law to outside the existing criminal procedure system or formal law?

After the in-depth research was carried out on the intended diversion institution, it was found that the settlement of cases or disputes as referred to in the definition of diversion does not completely remove the handling of a case or dispute to outside of a justice system. This is due to the understanding that in principle the justice is defined as an organization created by the State through the applicable law. Justice was created to examine and resolve legal disputes. And that in that understanding, all court functions are called justice, including justice functions that are outside the justice formal system.

Even though it is recognized that the definition is correct, it is said that the definition is not really accurate. Because the justice does not cover disputes; only covers criminal law cases. In reality, the decisions issued by the court do not concern case or dispute at all (non-contentious). However, even so, the handling of non-contentious legal problems is still covered in the understanding of the concept of justice.

In the procedures for diversion, evidence is found that in the procedures for diversion which are determined by the prevailing laws and regulations, judges and in this case the justice still play an important role, especially in determining the settlement of cases.

Therefore, as a starting point about justice in Indonesia, it has been given an understanding of justice as a guide in understanding what is meant by justice. The definition of the guide about justice begins with the explanation that the word "justice" (peradilan) comes from the root word "fair" (adil), which gets the prefix pe and the suffix an. Therefore, "justice" is defined as everything that relates to the court.

Court here is not interpreted as an abstract sense, namely "things to give justice". Or things related to the duties of a judicial body or a judge in providing justice. Namely giving to the person concerned, concretely to those who ask for justice regarding what becomes their right based on the law that regulates such matter.

It is argued that when a judge or court gives his/her rights or laws, they always base them on the applicable law. Which means nothing 
but implementing and maintaining the law or guaranteeing the compliance of material laws with decisions. This includes if there is no dispute or case, through a judge's ruling. For this reason, it can be said that they agree to the view that the justice is in all matters relating to the duties of judges in deciding cases. Both civil cases and criminal cases as well as other disputes.

It is necessary to state that in order to understand the procedures for diversion, the concept of criminal justice system (SPP) in general and the juvenile criminal justice system must be well understood. Therefore, it is necessary to state that what is meant by the criminal justice system in general, namely: "The Criminal Justice System is a system in society to tackle crime". Implicit in Mardjono Reksodipoetro's view, there is a process to overcome crime.

As stated, diversion is a process to tackle crime. It is just that the process points to efforts to "bring out" from the general criminal justice system. Furthermore, in the expression of overcoming crime there is an objective of the criminal law.

Referring to the definition of the juvenile criminal justice system in Law Number 11 Year 2012 concerning the Juvenile Criminal Justice System, the meaning of the concept of the juvenile criminal justice system can be found in Article 1 number (1). It is formulated there, that the juvenile criminal justice system is the entire process of solving cases of children in conflict with the law, from the investigation stage to the guidance stage after judicial process.

For a child who is in conflict with the law, the Juvenile justice system has implemented Diversion as stipulated in the Supreme Court Regulation Number 4 Year 2015. In line with these provisions, when viewed from the perspective of national law, this is in line with the judicial process as regulated in Law Number 11 Year 2012.

Ideas are thoughts about a certain object or phenomenon that are used as a benchmark or point of view orientation. Ideas will guide what to aspire to, so that ideas become a means of action, and ideas will be applied because they will be useful and successful in solving problems and determining human behavior. An idea is considered correct if the idea is needed to solve problems that arise in society. Thus, the idea serves to guide us to the reality. Starting from this understanding of idea, the definition of "diversion idea" is thought, the idea of diversion is used to guide in solving problems that arise in society ${ }^{24}$.

This is where it becomes important in the context of criminal policies regarding efforts to overcome children with problems with criminal law (perpetrators and/or victims); it becomes important to conduct studies on Provision of Laws concerning juvenile problems (perpetrators and victims) which are currently applicable (Ius Constitutum) and the practice of handling child perpetrators and/or victims carried out by law enforcement officials (ius operatum). The results of studies on substantive, procedural and cultural provisions on the ius constitutum and ius operatum on one hand and international instruments, the development of non-penal studies (including criminology) on the other hand, become input in the framework of establishing the desired criminal law (ius constituendum).

In a study of the Child Protection Legal System in Indonesia, it would be helpful to put forward the following statement by the State Minister for Woman Empowerment and Child Protection dated November 23, 2009:

Indonesia has ratified the Convention on the Rights of the Child through Presidential Decree Number 36 Year 1990, as a "state Pary" has the obligation to harmonize the Convention on the Rights of the Child in national law (forming a child protection legal system - cursive from the researcher), to implement action programs, to establish child human rights institutions, to make National Report annually; Ratification of the enactment of Law Number 23 Year 2002 concerning Child Protection;

Several laws have been enacted that can strengthen child protection, namely Law Number 23 Year 2004 concerning the Elimination of Domestic Violence; Law Number 12 Year 2006 concerning Citizenship, Law Number 13 Year 2006 concerning Protection of Witnesses and Victims, Law Number 23 Year 2006 concerning Population Administration, Law Number 21

\footnotetext{
24 Imam Wahyudi, Pengertian ide diversi telah disebutkan dalam BAB I dalam kerangka konsepsional. Jabaran kata "ide" ini berdasarkan mereka yang menganut Teori Kebenaran Pragmatis seperti Charles S. Pierce, William James, dan John Dewey. Lihat Pengantar Epistemologi (Yogyakarta: Badan Penerbit Filsafat UGM, LIMA 2007).
} 
Year 2007 concerning the Eradication of the Crime of Human Trafficking, judicial process for child pornography in Law Number 11 Year 2008 concerning Electronic Information and Transactions, and Law Number 44 Year 2008 concerning Pornography.

Substantially, this advanced step still needs to be reviewed, especially the level of compliance (consistency) of the law with the "soul" of the Child Protection Law and the Convention on the Rights of the Child.

In 2005, the National Development for Indonesian Children (2005-2015) was declared (State Minister for Woman Empowerment, 2009).

This quote can more or less be used as an indicator or parameter that there is a need to conduct in-depth studies of the substance and legal structure of all provisions of laws relating to Child Protection in Indonesia, mainly examined from the compliance (consistency) of principles, rules, and institutions that is governed by provisions of laws relating to Child Protection.

On the other hand, a study of the Law which is the Legal Basis for the Procedure for Handling of Delinquent Children (Criminal Code and Law Number 11 Year 2012) indicates that there are substantive and structural weaknesses. "Mistakes" in handling Raju more or less give an indication that there is a substantive weakness in Law Number 11 Year 2012 which refers Criminal Code so that there are no provisions regarding the termination of case.

The application of Law Number 11 Year 2012 in practice indicates the existence of stigmatization of children. The results of observation of the judges' decisions regarding children so far have shown a high tendency for judges to impose criminal sanctions on delinquent children rather than action or treatment. The punishments that were imposed were generally in the form of imprisonment. It can be said that the supervision punishment as stipulated in Law Number 11 Year 2012 is almost never imposed by the judges.

The results of interviews with a number of juvenile court judges stated that if you want to impose supervisory punishment, who will be the supervisor? It also reflects on the one hand that Law Number 11 Year 2012 is substantively and structurally weak, and on the other hand Ius Operatum which is factually implemented is not fully implemented well with the basic principles of the purpose for which this Law is promulgated (seen from the preamble).

From all the expressions and studies mentioned above, it is important that this country, in its future steps in the context of legal reform, needs to pay attention to the importance of building an adequate "legal system" for children. What has so far been seen in the regulations concerning Child Protection, both children as victims and children as perpetrators, is still fragmentary in nature, not fully reflecting a "Legal System". Child protection shall be based on children's grundnorm, namely The Best Interest of the Child.

Paying attention to the various weaknesses contained in the substantive provisions of the laws and regulations regarding Child Protection (perpetrators or victims) in this country, on the one hand, and on the other hand the limited capacity of the criminal law, which is only an anticipatory step which is "kurieren et symptom" overcoming existing symptoms, without touching the root of the problem, while the background factors for the occurrence of symptoms of mistreatment of children both as perpetrators and as victims, it is no exaggeration for future legal reform policy steps (ius constituendum) to consider the development of society of observers of children at the world level, which concerns the implementation of restorative justice for children.

\section{CONCLUSION}

The current ideal construction for children who are in conflict with the law is to apply Law Number 12 Year 2011 concerning Children Courts where children aged 7 years can be given diversion in the trial process as regulated in the Regulation of the Supreme Court of the Republic of Indonesia Number 4 Year 2014 concerning Guidelines for the Implementation of Diversion In the Juvenile Criminal Justice System that the child must be subjected to diversion if they commit a criminal act, whereas in Article 21 of the Child Protection Law, in the event that a child under 12 (twelve) years old commits or is suspected of committing a criminal act, he/she is returned to their parents and enrolled in the education program, coaching and mentoring in government institutions or Social Welfare Organizing Institutions in agencies dealing with social welfare. The ideal reconstruction is to apply diversion to all children, without exception, who have committed criminal 
acts as stipulated in Law Number 12 Year 2011 without any discrimination.

\section{SUGGESTION}

Courts shall apply diversion in the trial process to overcome crimes by pointing to efforts to "bring out" from the general criminal justice system in juvenile criminal cases.

\section{ACKNOWLEDGMENT}

The researcher would like to thank the supervisors in the writing of this Scientific Paper so that it can be maximized in the method and substance, including Mr. Syprianus Aristeus and Mr. Ahyar Arigayo and other research colleagues who provided input and advice in the writing process, as well as the Research and Development Board for Law and Human Rights, the Ministry of Law and Human Rights where the researcher carried out his duties as a Legal Researcher.

\section{BIBLIOGRAPHY}

Ahmad Syafiq. "Rekonstruksi Pemidanaan Dalam Hukum Pidana Islam (Perspektif Filsafat Hukum)." Jurnal Pembaharuan Hukum 1, no. 2 (2014): 179.

Ahmad Ubbe. Mediasi Penal dan Peradilan Adat. Jakarta, 2014.

Ali, Muhammad Khalid. "Rekonstruksi Pengaturan Persidangan Tanpa Hadirnya Terdakwa Tindak Pidana Korupsi Dalam Sistem Peradilan Pidana Indonesia." Brawijaya, 2019.

Antonius Cahyadi. Runtuhnya Sekat Perdata dan Pidana: Studi Peradilan Kasus Kekerasan Terhadap Perempuan. Jakarta: Yayasan Obor Indonesia, 2008.

Article 11.1. "The Beijing Rules.” Article 11.1. Beijing, 1985.

Bryan A. Garner (ed). Black's Law Dictionary. St. Paul, 2000.

Imam Wahyudi. Pengertian ide diversi telah disebutkan dalam BAB I dalam kerangka konsepsional. Jabaran kata "ide" ini berdasarkan mereka yang menganut Teori Kebenaran Pragmatis seperti Charles S. Pierce, William James, dan John Dewey.
Lihat Pengantar Epistemologi. Yogyakarta: Badan Penerbit Filsafat UGM, LIMA, 2007.

Jufrina Rizal, Suhariyono AR. Demi Keadilan Antologi Hukum Pidana dan Sistem Peradilan Pidana. Jakarta: Pustaka Kemang, 2016.

Lilik Mulyadi. Pengembalian Aset (Asset Recovery) Pelaku Tindak Pidana Korupsi. Jakarta: Kencana, 2020.

—. Wajah Sistem Peradilan Pidana Anak Indonesia. Bandung: Alumni, 2014.

Lode Walgrave. Restoration in Youth Justice. Chicago: University of Chicago, 2004.

Marlina. Peradilan Pidana Anak di Indonesia. Jakarta: Refika Aditama, 2012.

Muhaimin. "Penetapan Tersangka Tidak Ada Batas Waktu." Jurnal Penelitian Hukum De Jure 20, no. 2 (2020): 278. https://ejournal. balitbangham.go.id/index.php/dejure/article/ view/1165/pdf_1.

Paulus Hadisuprapto. "Peradilan Restoratif Model Peradilan Anak Indonesia Masa Datang, Pidato Pengukuhan Guru Besar dalam Bidang Kriminologi pada Fakultas Hukum Universitas Diponegoro Semarang, tanggal 18 Februai 2006," 2006.

Peter Mahmud Marzuki. Penelitian Hukum. Jakarta: Kencana Prenada Media Group, 2006.

Situmorang, Mosgan. "Aspek Hukum Pemberantasan Tindak Pidana Korupsi Oleh Korporasi Dalam Bidang Perpajakan." Penelitian Hukum De Jure 20, no. 3 (2020): 337. https://ejournal.balitbangham.go.id/ index.php/dejure/article/view/1280/pdf.

Undang-undang Republik Indonesia No. 11 Tahun 2012 Tentang Sistem Peradilan Pidana Anak. Diversi sebagaimana dimaksud pada ayat (1) dilaksanakan dalam hal tindak pidana yang dilakukan: $a$. diancam dengan pidana penjara di bawah 7 (tujuh) tahun; dan b. bukan merupakan pengulangan tindak pidana". Jakarta, 2012. -. Pasal 9 ayat (2) UU SPPA, menegaskan: "Kesepakatan Diversi harus mendapatkan persetujuan korban dan/atau keluarga Anak korban serta kesediaan Anak dan 
keluarganya, kecuali untuk: a. tindak pidana yang berupa pelanggaran; $b$. tindak pidana ringan; c. tindak, 2012.

UU No. 35 Tahun 2014. Pasal 59 "Pemerintah dan Lembaga negara lainnya berkewajiban dan bertanggungjawab untuk memberikan perlindungan khusus kepada anak dalam situasi darurat, anak yang berhadapan dengan hukum, anak dari kelompok minoritas dan teresolasi, anak tereksplotasi se. Jakarta, 2014. 
HALAMAN KOSONG 